\title{
Using of Chêneau brace for early onset scoliosis treatment
}

\author{
D Chekryzhev*, A Mezentsev, D Petrenko \\ From 9th International Conference on Conservative Management of Spinal Deformities - SOSORT 2012 \\ Annual Meeting \\ Milan, Italy. 10-12 May 2012
}

\section{Background}

Casting, halo-traction [1,2], Milwaukee or TLSO braces $[1,3]$ are routinely used for the conservative treatment of early onset scoliosis (EOS). Some authors use brace only in a case of congenital scoliosis absence.

\section{Aim}

The purpose of this study is to assess outcomes of Chêneau brace use in EOS patients.

\section{Methods}

This is a prospective study of clinical outcomes in 17 EOS patients treated with Chêneau brace. Mean age was 4.3 years old. Follow-up was 2-7 years. There were 3 males and 14 females. 3 patients had mixed spinal anomaly (1st group), 10 patients had wedge hemivertebra (2nd group) and 4 patients had infantile idiopathic scoliosis (3rd group).

\section{Results}

Before treatment initiation, Cobb angle in the 1st group was $52.3^{\circ}\left(43^{\circ}-60^{\circ}\right)$, in the 2nd group $33.2^{\circ}\left(25^{\circ}-48^{\circ}\right)$, and in the 3rd group $40^{\circ}\left(24^{\circ}-75^{\circ}\right)$. After 6 years follow-up on the 1st group, 1 patient had $7^{\circ}$ correction, 1 patient had $8^{\circ}$ progression and 1 patient had stable deformity. In the 2nd group, mean correction was $3^{\circ}\left(-2^{\circ}-15^{\circ}\right)$ and $8.75^{\circ}\left(0^{\circ}-30^{\circ}\right)$ in the 3 rd group.

\section{Conclusion}

Using a Chêneau brace results in getting EOS correction in $7(41 \%)$ cases, stabilized deformity in 8 cases (47\%), and in $2(12 \%)$ cases progression was delayed. The results

Sytenko Institute of Spine and Joint Pathology, Orthospine LTD, Kharkiv, Ukraine are the best we get in patients with infantile idiopathic scoliosis.

Published: 3 June 2013

\section{References}

1. Fletcher ND, Larson AN, Richards BS, Johnston CE: Current treatment preferences for early onset scoliosis: a survey of POSNA members. J Pediatr Orthop 31(3):326-330.

2. D'Astous $J$, Sanders JO: Casting and traction treatment methods for scoliosis. Orthop Clin North Am 2007, 38(4):477-484, v.

3. Yazici M: Non-Idiopathic Spine Deformities in Young Children.978-3-64219416-0.

\section{doi:10.1186/1748-7161-8-S1-053}

Cite this article as: Chekryzhev et al:: Using of Chêneau brace for early onset scoliosis treatment. Scoliosis 2013 8(Suppl 1):O53.

Submit your next manuscript to BioMed Central and take full advantage of:

- Convenient online submission

- Thorough peer review

- No space constraints or color figure charges

- Immediate publication on acceptance

- Inclusion in PubMed, CAS, Scopus and Google Scholar

- Research which is freely available for redistribution 